\title{
Morphology of the Early Jurassic Arietitidae and the effects of syn vivo serpulid infestations
}

\author{
Michael Ramming ${ }^{1}$, Dieter Korn ${ }^{1}$, Carina Klein ${ }^{1}$, and Christian Klug ${ }^{2}$ \\ ${ }^{1}$ Museum für Naturkunde Berlin, Leibniz-Institut für Evolutions- und Biodiversitätsforschung, \\ Invalidenstraße 43, 10115 Berlin, Germany \\ ${ }^{2}$ Paläontologisches Institut und Museum, Karl Schmid-Strasse 4, 8006 Zürich, Switzerland \\ Correspondence: Dieter Korn (dieter.korn@mfn-berlin.de)
}

Received: 8 January 2018 - Revised: 15 February 2018 - Accepted: 19 February 2018 - Published: 20 March 2018

\begin{abstract}
Selected specimens from the Jurassic ammonoid family Arietitidae were investigated using morphometric methods of transverse and longitudinal conch section analysis. The family Arietitidae is characterized by similarities in the conch geometry, but variation can be demonstrated by means of differences in conch morphology. Our study focuses on a specimen of the arietitid Pararnioceras sp., which revealed striking changes in conch morphology due to a syn vivo growth through a parasitic serpulid. Changes in its ontogenetic development are compared with specimens without epizoans. The ecological interpretation of the morphometric data allows the conclusion that the host possessed the ability to counteract the parasitic conch abnormalities by adapting its housing growth, thus ensuring survival.
\end{abstract}

\section{Introduction}

In the 19th century, research on the Jurassic period had already revealed the stunning diversity and disparity of its ammonite faunas (e.g. Orbigny, 1842; Quenstedt, 1858, 18851888; Hyatt, 1889; Wähner, 1895). Unsurprisingly, it was the same people who also discovered remains of other organisms attached to the ammonite conchs, either syn vivo or post mortem. Among Jurassic ammonites, representatives of the Arietitidae are remarkable because of the combination of their often large size (up to almost one metre; Stevens, 1988), great abundance (and correspondingly their ecological importance), and also their role in the Early Jurassic rediversification (e.g. Donovan et al., 1981; Neige et al., 2013).
The fossil record has been yielding countless ammonoid specimens, whose conchs show signs of anomalies. Similarly, remains of other organisms settling on ammonoid conchs are quite common (e.g. Seilacher, 1960, 1982; Stilkerich et al., 2017). Evidence for an organism settling on an ammonoid conch syn vivo can mainly be found in the reaction to this epizoan by the ammonoid animal and the specific orientation of the epizoan (Seilacher, 1960; Meischner, 1968; Keupp et al., 2011). Since many organisms inhabited ammonoid conchs post mortem, Davis et al. (1999) differentiated between post-mortem epicoles and syn vivo epizoans (Linck, 1956; Klug and Korn, 2001). Hölder (1956) classified such anomalies caused by epizoans in terms of a forma aegra nomenclature, the use of which Keupp (2012) continued in an extensively illustrated work with numerous illustrated examples of a wide range of anomalies in ammonoids (see also Hengsbach, 1991, 1996; Hoffmann and Keupp, 2015). Cases in which deformation of the shell and/or deviation from the normal planispiral coiling were caused by encrusters provide incontrovertible evidence that the encrusters colonized the shell while the host lived (Checa et al., 2002; Luci and Cichowolski, 2014). A parasitic nature, but not only this, can be assumed to be the cause of some abnormal malformations of ammonoid conchs (a review over parasitoses can be found in De Baets et al., 2015). These parasitoses were defined by Keupp (2012) as "organismic interrelationships in which a parasite in or on an organism is temporarily or permanently determined and permanently damages its host".

If parasitoses occur with Recent representatives of cephalopods as described in the form of the negative interaction of Nautilus pompilius and the copepod Anchicaligus nautili (Haven, 1972; Ho, 1980), an examination of the in- 
terrelationship with infected specimens syn vivo is possible. Investigations of parasitoses in fossil cephalopod species, for example of the Ammonoidea, can only be corroborated by conch abnormalities on the basis of the fossilized shell material unless the culprit's shell is also preserved (De Baets et al., 2011). Parasitic worms (for a discussion why commensalism is unlikely, see Zapalski, 2011) which colonized the outer side of a conch of the living host by forming a tube (syn vivo growth) can be identified easily by means of the preserved worm tube (Fig. 1). Worms identified as epizoans (Keupp et al., 2011) have been widely described in the literature (Ehrenberg, 1932; Lange, 1932; Schindewolf, 1934; Merkt, 1966; Holland, 1971; Buys, 1973; Landman and Waage, 1986; Nicosia, 1986; Turek, 1987; Jäger, 1991; Rakús and Zítt, 1993; Fraaye and Jäger, 1995; Checa et al., 2002; Hoffmann and Keupp, 2015; Tajika et al., 2015) as well as post mortem epicoles (e.g Seilacher, 1982; Schmid-Röhl and Röhl, 2003).

A thorough review of ammonites with syn vivo growth of epizoans was given by Andrew et al. (2011), who figured a number of specimens of the Early Jurassic Promicroceras with serpulid overgrowth. They discussed the ecological importance of the interspecies relationships and the consequences of serpulid infestation for the host. They also demonstrated that the most beneficial position for the serpulid would by an upside down position of its aperture or an apertural position at 6 o'clock on the venter of the ammonite conch.

We investigated a sectioned specimen of Pararnioceras sp. in greater detail and discuss it in the frame of the family Arietitidae; the specimen displays a syn vivo infestation by an annelid that probably belongs to the family Serpulidae. The epizoan worm is clearly visible in the cross section of the specimen, where it is represented by its mineralized tube over three half-volutions between 8 and $17 \mathrm{~mm}$ conch diameter (Fig. 2). The specimen was examined for changes in growth before, during, and after the infestation. We address the question of how the ammonite compensated for the irritation caused by the worm by active growth alteration. The focus of our investigation is not on the morphology of the worm tube but on the morphological changes of the ammonite host using morphometric methods. For comparative purposes, we studied specimens of other, normally grown individuals of some species of the family Arietitidae using morphometric data of cross sections and longitudinal sections.

\section{Material and methods}

\subsection{Cross sections}

Our investigation of conch ontogeny in the family Arietitidae is mainly based on cross sections. This method allows the collection of large morphometric data sets (e.g. Korn, 2010; Klug et al., 2015), which optimally represent the entire ontogeny of the ammonites under investigation. The mor-

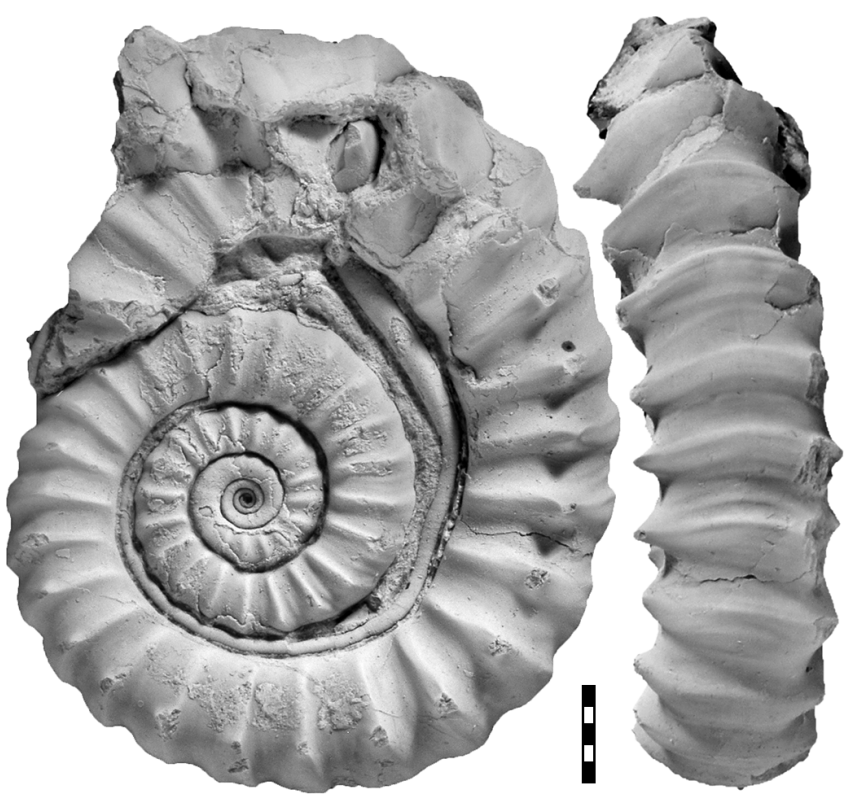

Figure 1. Promicroceras capricornoides (Quenstedt, 1884), specimen PIMUZ 23185 (Chandler Coll.) from Black Ven 2, Charmouth (Dorset, UK), lateral and ventral views. Scale bar units $=1 \mathrm{~mm}$.

phometric parameters and ratios taken from the cross sections for the study of the conch ontogeny are, following Korn (2010), conch diameter (dm), whorl width (ww) and whorl height (wh). The following parameters and ratios can be calculated on the basis of these measured values: umbilical width (uw), aperture height (ah); and the ratios and indexes (Fig. 3) conch width index (CWI), whorl width index (WWI), umbilical width index (UWI) and whorl expansion rate (WER).

The specimens are stored in the cephalopod collection of the Museum für Naturkunde, Berlin (catalogue numbers MB.C.) and the Paläontologisches Institut und Museum, Zürich (catalogue number PIMUZ).

The following specimens were sectioned (with the range of preserved volutions):

MB.C.15812 (Krüger Coll.), Pararnioceras sp. from Pabstorf near Halberstadt: 22-186 mm conch diameter (Fig. 4a-c).

MB.C.14986 (Ewald Coll.), Pararnioceras sp. from Pabstorf near Halberstadt: $42-143 \mathrm{~mm}$ conch diameter (Fig. 4d-f).

MB.C.27408 (formerly Technical University Berlin Coll.), Coroniceras sp. from the Heinemann claypit near Oelber am weißen Wege: 18-96 mm conch diameter (Fig. 4g-i).

MB.C.27997 (formerly Technical University Berlin Coll.), Pararnioceras sp. from Balingen: about $115 \mathrm{~mm}$ 

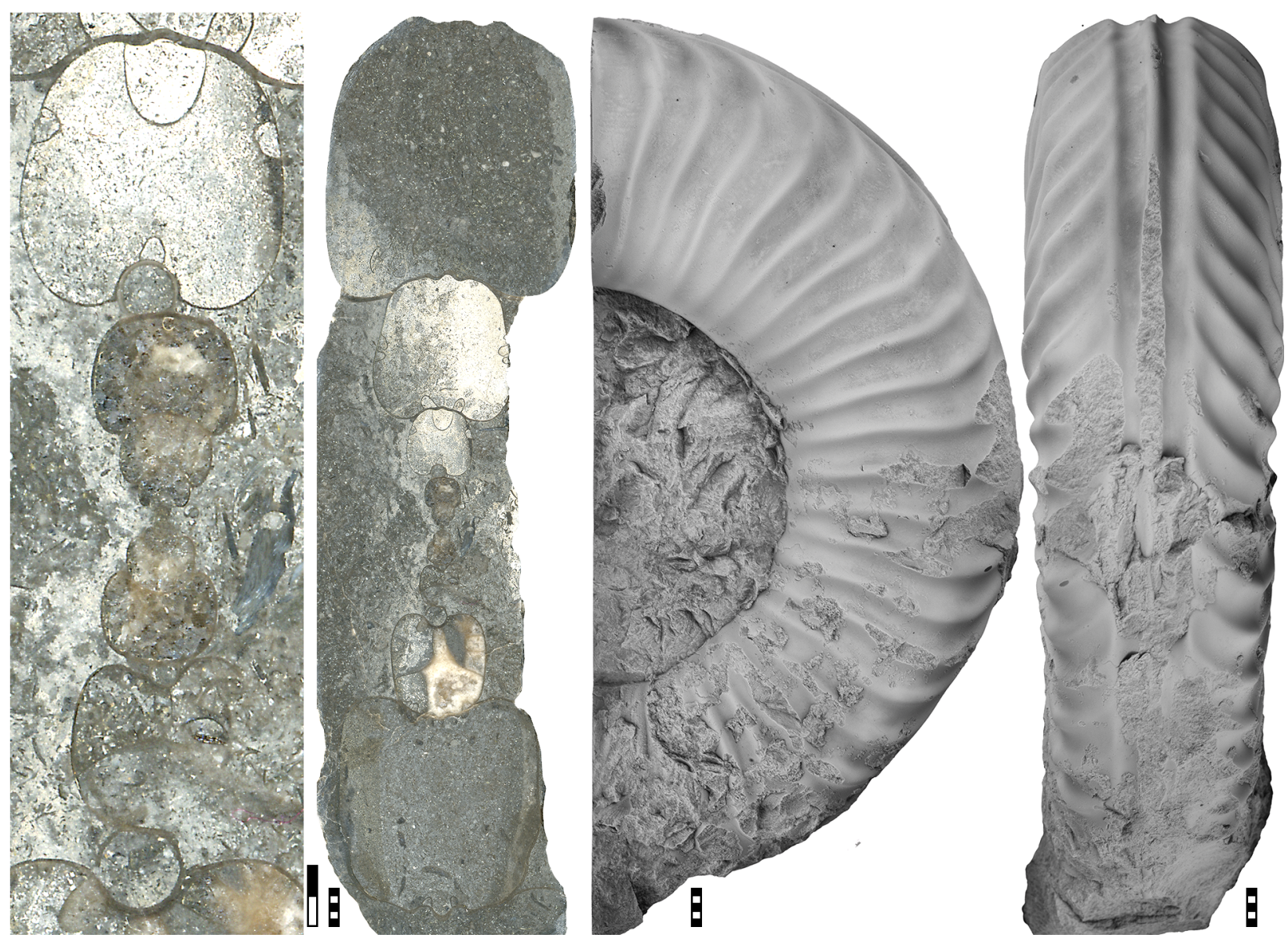

Figure 2. Pararnioceras sp., specimen MB.C. 27997 (formerly Technical University Berlin Coll.) from Balingen, conch cross sections, lateral and ventral views. Scale bar units $=1 \mathrm{~mm}$.

conch diameter, embedded in dark grey limestone, the entire ontogeny can be studied (Fig. 5a-c).

MB.C.15950.1 (Lange Coll.), Asteroceras obtusum (Sowerby, 1817) from the Gesellschaftsziegelei in Bielefeld: $61 \mathrm{~mm}$ conch diameter, the entire ontogeny can be studied (Fig. 5d-f).

MB.C.14961 (Ewald Coll.), Arnioceras sp. from Asse near Wolfenbüttel: $53 \mathrm{~mm}$ conch diameter, the entire ontogeny can be studied (Fig. $5 \mathrm{~g}-\mathrm{i}$ ).

\subsection{Longitudinal sections}

We obtained conch diameters from longitudinal (sagittal, in the plane of symmetry) sections in two ways, using distances of 10 and 90 degree angles (Fig. 6). The whorl expansion rate was then calculated for these growth increments for documentation of the coiling principles of the species under study. In a second approach, we measured the distance of the phragmocone septa (angle $\alpha$ ) for an analysis of accelerated or decelerated growth of the specimens.
MB.C.15736 (von Fischer Coll.), Coroniceras rotiforme (Sowerby, 1825) from Württemberg, Germany: 25-154 mm conch diameter (Fig. 6a, b).

MB.C.3673, Asteroceras stellare (Sowerby, 1815) from Lyme Regis in Dorset (UK): $8-230 \mathrm{~mm}$ conch diameter (Fig. 6c, d).

\section{Results}

\subsection{Conch morphology of arietitid ammonites}

All representatives of the family Arietitidae share a number of conch characteristics, which are variable within genera and species with rather narrow limits:

1. The adult conch is thinly discoidal (ww/dm $=0.20$ 0.30 ) and evolute (uw/dm $>0.50$ in most specimens of Arietites, Coroniceras and Pararnioceras) or, less common, subevolute (uw/dm $=0.40$ in Asteroceras).

2. The whorl profile is often nearly circular or quadrate $(\mathrm{ww} / \mathrm{wh}=1.00)$ with parallel or subparallel flanks. 


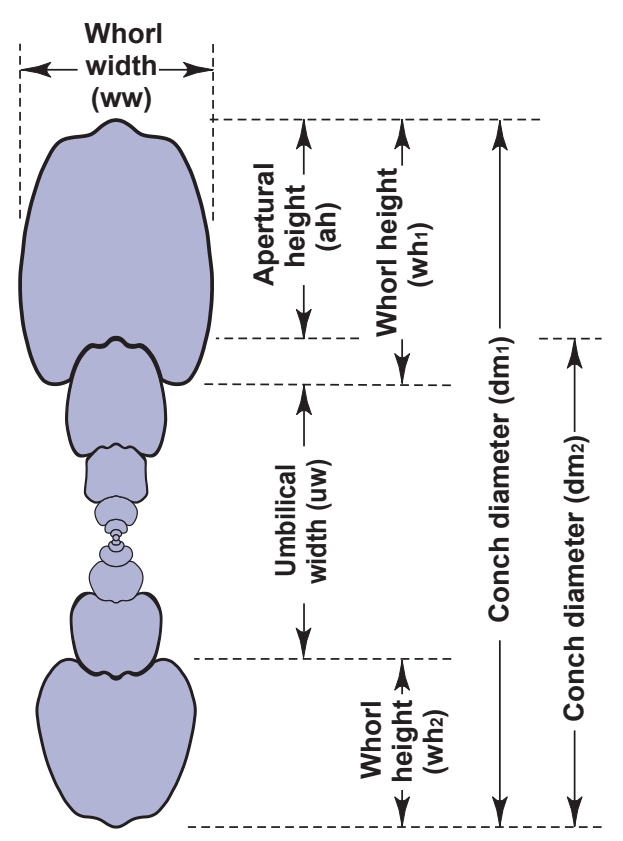

Figure 3. Conch dimensions, ratios and rates obtained from ammonoid conch cross sections.

3. The venter is characterized by a median keel that is accompanied on both sides by more or less pronounced longitudinal grooves.

\subsection{Conch ontogeny of arietitid ammonites}

Analyses of the morphometric conch data revealed recurring patterns in the ontogenetic development of cardinal conch parameters. The conch ontogeny of arietitid ammonites is very similar between species, as outlined by the two rather different species Asteroceras obtusum (subevolute, depressed to compressed whorl profile; Fig. 5d-f) and Arnioceras sp. (evolute, compressed whorl profile; Fig. $5 \mathrm{~g}-\mathrm{i}$ ), both of which are available as conch cross sections beginning with the first whorl. The results are complemented by some cross sections in which the inner whorls are not preserved. The most characteristic features are as follows:

1. The conch width index (ww/dm) decreases during ontogeny;

Arnioceras sp.: from $\sim 0.45$ at $1.5 \mathrm{~mm} \mathrm{dm}$ to $\sim 0.18$ at $50 \mathrm{~mm} \mathrm{dm}$,

Asteroceras obtusum: from $\sim 0.75$ at $1.5 \mathrm{~mm} \mathrm{dm}$ to $\sim 0.28$ at $50 \mathrm{~mm} \mathrm{dm}$.

It appears that this trend is not linear as it is decelerated in relatively large specimens, as seen in Pararnioceras sp. between 30 and $200 \mathrm{~mm}$ conch diameter (Fig. 4).

2. The umbilical width index (uw/dm) increases during ontogeny;
Arnioceras sp.: from $\sim 0.20$ at $1.5 \mathrm{~mm} \mathrm{dm}$ to $\sim 0.50$ at $50 \mathrm{~mm} \mathrm{dm}$,

Asteroceras obtusum: from $\sim 0.20$ at $1.5 \mathrm{~mm} \mathrm{dm}$ to $\sim 0.40$ at $50 \mathrm{~mm} \mathrm{dm}$.

This trend is monophasic in both specimens and can also be observed in the large specimens of Pararnioceras sp. (Fig. 4).

3. The whorl expansion rate (WER) decreases during ontogeny;

Arnioceras sp.: from $\sim 2.50$ at $1.5 \mathrm{~mm} \mathrm{dm}$ to $\sim 1.75$ at $50 \mathrm{~mm} \mathrm{dm}$,

Asteroceras obtusum: from $\sim 2.20$ at $1.5 \mathrm{~mm} \mathrm{dm}$ and 2.30 at $10 \mathrm{~mm} \mathrm{dm}$ to $\sim 2.10$ at $50 \mathrm{~mm} \mathrm{dm}$.

The ontogenetic trend in coiling is not linear and shows a phase of stagnation in both specimens. The large specimens of Pararnioceras sp. show a slow and continuous decrease of the WER from 1.75 at $40 \mathrm{~mm}$ diameter to 1.55 at $195 \mathrm{~mm}$ diameter dm (Fig. 4).

These patterns of allometric conch growth differ markedly from most of the Palaeozoic and Triassic ammonoids, which usually show negative allometry of the umbilical width index and a positive allometry of the whorl expansion rate (e.g. Korn, 2012). Even in Palaeozoic and Triassic ammonoids which possess evolute conchs, there is usually an adult decrease of the uw/dm ratio and an increase or stagnation of the whorl expansion rate (Klug, 2001; Walton and Korn, 2017). Representatives of the Late Devonian families Platyclymeniidae, Clymeniidae and Kosmoclymeniidae, for instance show an adult change towards a compressed whorl profile and weak reduction of the umbilical width index (e.g. Korn and Price, 1987; Korn, 2002; Nikolaeva and Bogoslovsky, 2005). The whorl expansion rate oscillates within limits in these forms without a clear trend. A similar situation can be seen in evolute Middle Devonian genus Lunupharciceras (Bockwinkel et al., 2009) and in the Middle Permian genus Paraceltites (Spinosa et al., 1975).

4. The angular length of the phragmocone chambers decreases during growth. This ontogenetic trend, however, is occasionally interrupted by intervals where greater and smaller septum distances occur (Fig. 6). The variation of septum distances can be interpreted by changes in the growth rate during the ontogenetic development of the ammonite conchs, which can occur, for example, when the adult stage is reached (Westermann, 1971). Also adverse environmental factors such as temperature or food availability may cause septal crowding (Bucher et al., 1996; Kraft et al., 2008). Parasitic infestations might locally also effect septal spacing (e.g. De Baets et al., 2013). 

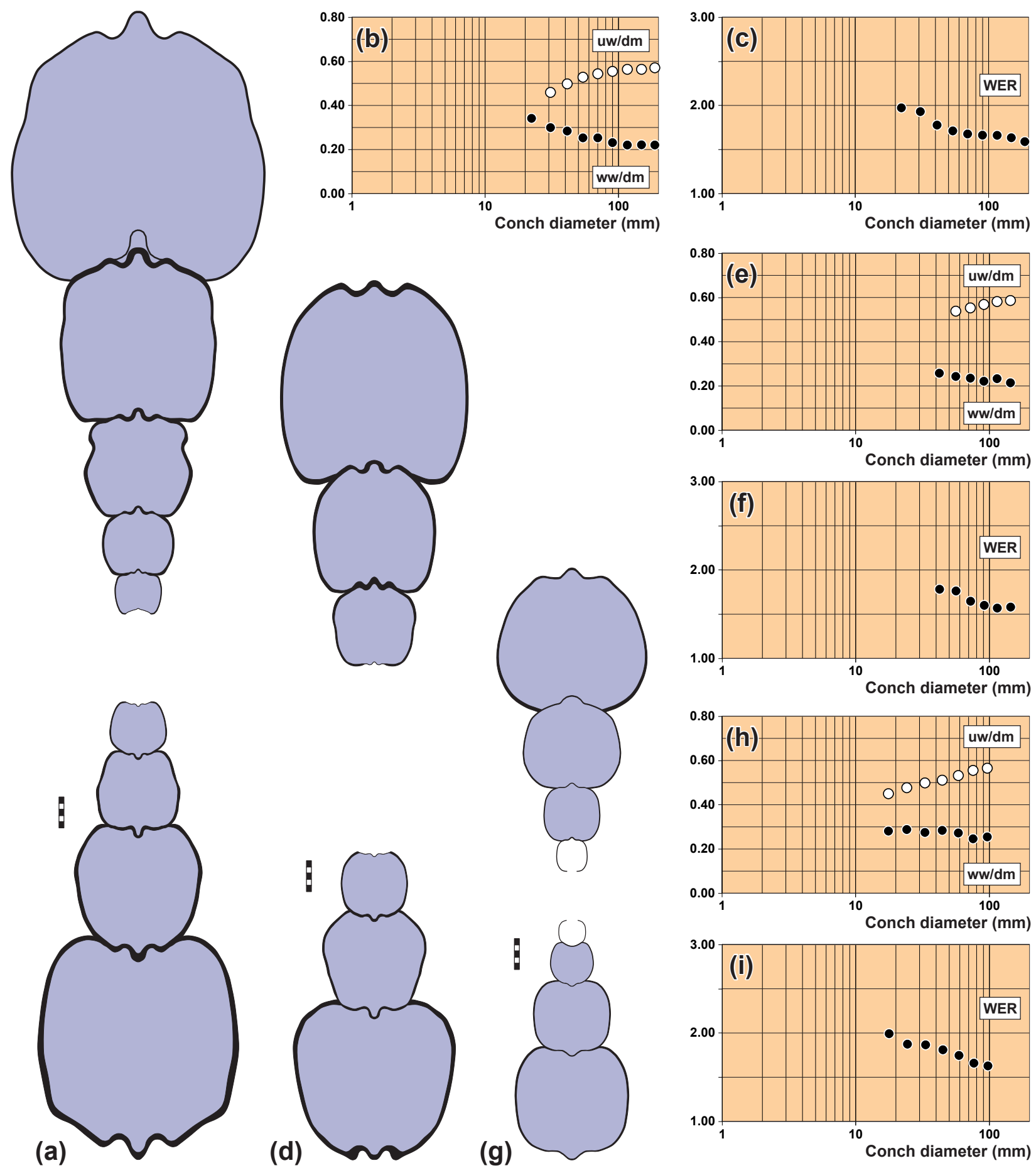

Figure 4. Conch cross sections and ontogenetic trajectories of whorl width index (ww/dm), umbilical width index (uw/dm) and whorl expansion rate (WER) in arietid specimens. (a-c) Pararnioceras sp., specimen MB.C.15812 (Krüger Coll.) from Pabstorf near Halberstadt. (d-f) Pararnioceras sp., specimen MB.C.14986 (Ewald Coll.) from Pabstorf near Halberstadt. (g-i) Coroniceras sp., specimen MB.C.27408 (formerly Technical University Berlin Coll.) from Oelber am weißen Wege. Scale bar units $=1 \mathrm{~mm}$. 


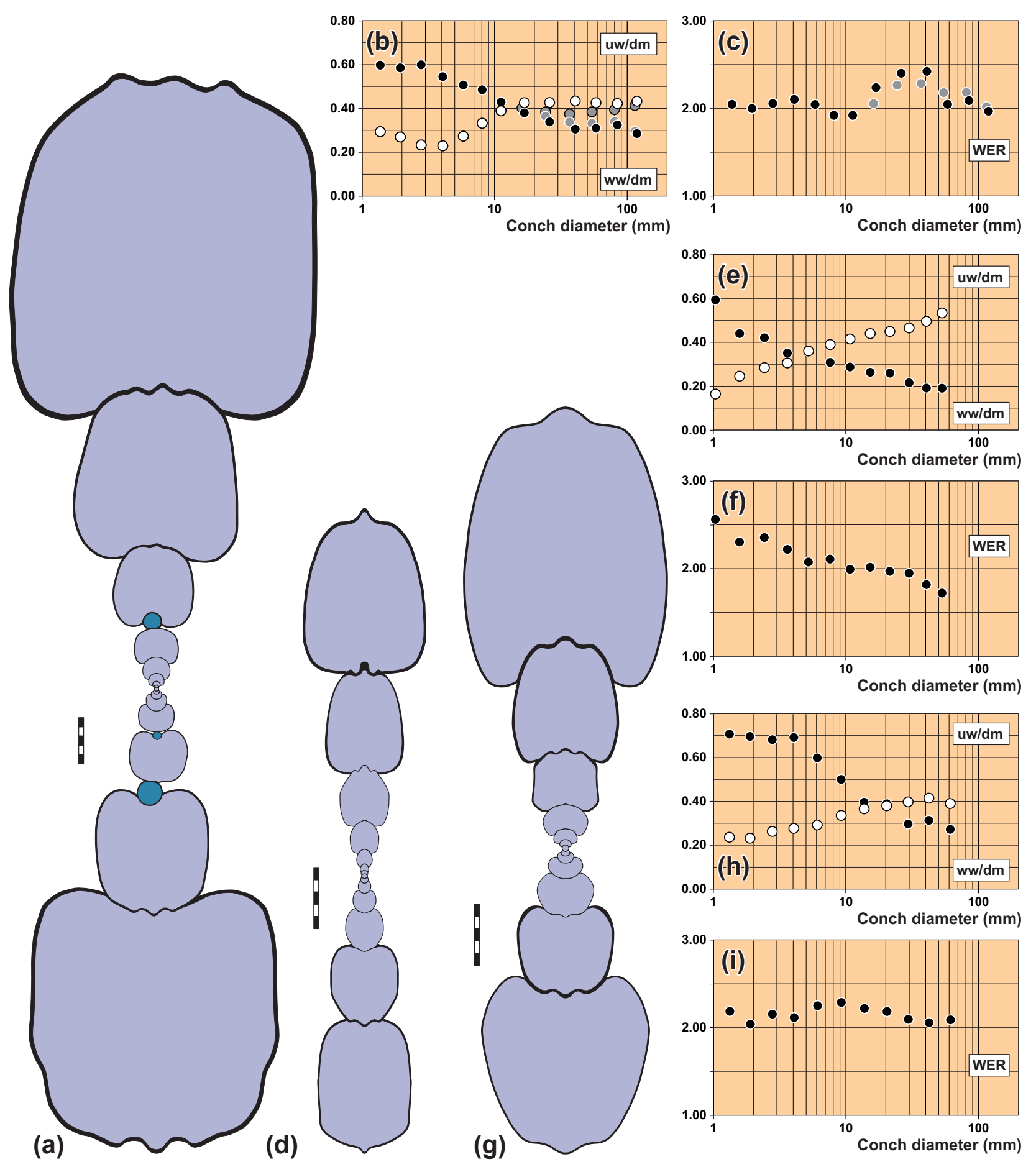

Figure 5. Conch cross sections and ontogenetic trajectories of whorl width index (ww/dm), umbilical width index (uw/dm) and whorl expansion rate (WER) in arietid specimens. (a-c) Pararnioceras sp., specimen MB.C. 27997 (formerly Technical University Berlin Coll.) from Balingen. (d-f) Arnioceras sp., specimen MB.C.14961 (Ewald Coll.) from Asse near Wolfenbüttel. (g-i) Asteroceras obtusum (Sowerby, 1817), specimen MB.C.15950.1 (Lange Coll.) from the Gesellschaftsziegelei in Bielefeld. Scale bar units $=1 \mathrm{~mm}$. 

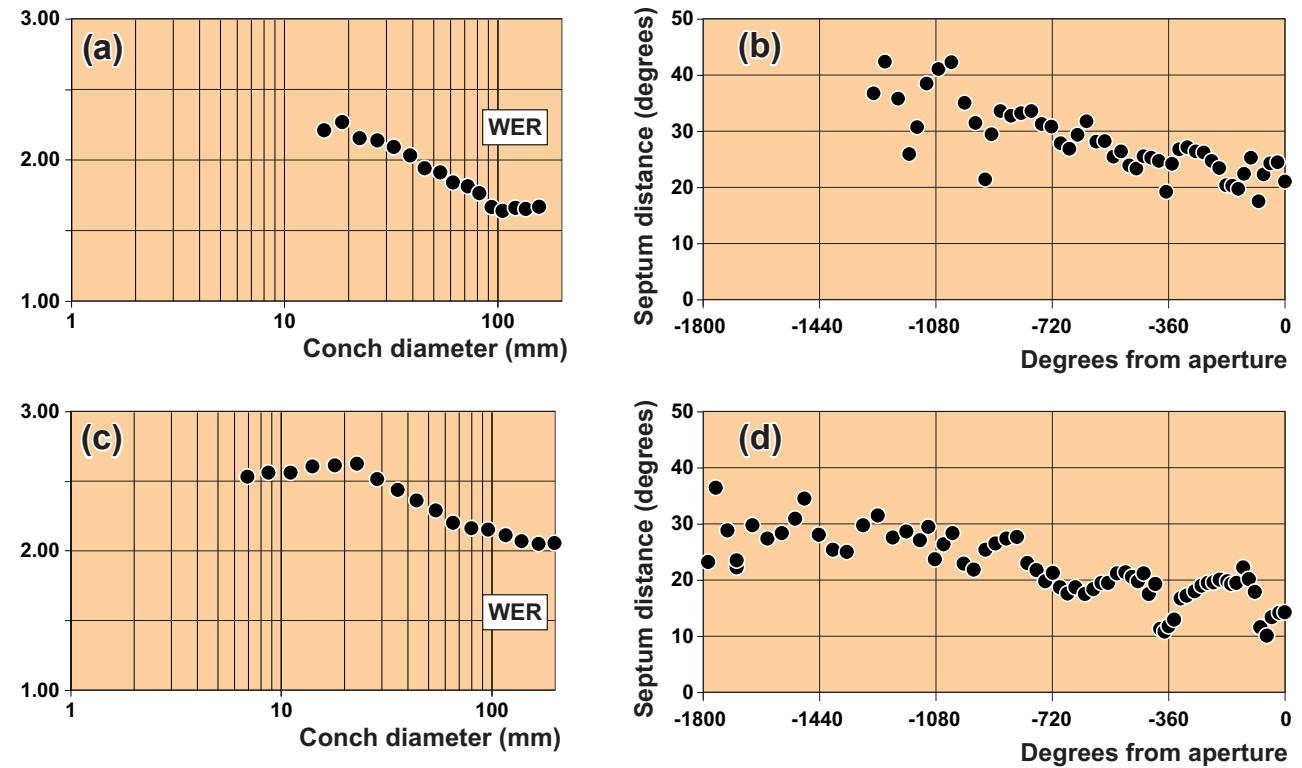

Figure 6. Septal distances (in degrees) and whorl expansion rate (WER) obtained from longitudinal sections of arietid specimens. (a, b) Coroniceras rotiforme (Sowerby, 1824), specimen MB.C. 15736 (von Fischer Coll.) from Württemberg, Germany. (c, d) Asteroceras stellare (Sowerby, 1815), specimen MB.C.3673 from Lyme Regis in Dorset.

\subsection{Morphometric examination of specimen MB.C.27997 (Pararnioceras sp.)}

Specimen MB.C.27997 was sectioned through the initial chamber in order to uncover how the worm infestation changed the morphological development of some of the conch parameters and to what degree such changes occurred. It can be seen from the cross-sectional drawing (Fig. 5a) that the worm grew on the venter of the ammonite conch over a distance of between one and a half and two whorls. The position of the worm tube changes slightly, during the growth of the ammonite the aperture of the worm tube migrated from a nearly central position on the venter to the left side of the venter, occupying a position in the ventrolateral groove.

The conch ontogeny of the worm tube bearing specimen shows a number of characteristics deviating from other conspecific specimens in some, but not all traits (Fig. 5a-c):

1. The conch width index (ww/dm) is negatively allometric and biphasic; it is stable at 0.60 between 1 and $3 \mathrm{~mm}$ diameter and thereafter decreases to 0.30 at a $100 \mathrm{~mm}$ diameter. In this respect the specimen closely resembles specimen MB.C.15950.1 (Asteroceras obtusum).

2. The umbilical width index (uw/dm) is positively allometric and triphasic; after a juvenile decrease, it increases, in the growth interval between 4 and $11 \mathrm{~mm}$ diameter, from 0.23 to about 0.40 and later remains at this value. In this respect, there are also similarities with specimen MB.C.15950.1.
3. The whorl expansion rate oscillates between 1.90 and 2.10 in the growth interval between 1 and $12 \mathrm{~mm}$ diameter without a clear trend. Thereafter, a steep increase to 2.40 at 26 and $42 \mathrm{~mm}$ diameter follows with a subsequent sudden decline to a value of 2.05 at $58 \mathrm{~mm}$ diameter. The data suggest that this increase in the coiling rate was caused by the overgrowth of the worm tube on the venter of the ammonoid conch and the modified geometry. However, a reconstruction of the conch without the worm tube leads to an interesting result; the coiling rate is increased even when the worm tube is removed and the whorls would weakly embrace the preceding whorl as typical of the species (Fig. 5b, c). This can be interpreted as a reaction of the whorl height to the worm infestation.

4. During the interval of infestation by the worm on the ammonite's venter, the animal was not able to attach its new whorls to the preceding whorl. The ammonite therefore used the worm tube as the contact surface. This happened in such a way that the centre of the dorsal side was aligned to the tube (Figs. 2, 5a).

5. To stabilize the upright position of the specimen in the water column, rotation of the whorl profile was necessary (compare Stilkerich et al., 2017) (Fig. 5a). This rotation is visible in the inclination of the whorls beginning with the infestation on the venter. The whorl profile half a volution prior to the first visible tube on the venter is unaffected, which can be seen as evidence for an infestation between the eighth and the tenth half whorl. 
Examination of the conch parameters in the specimen leads to the conclusion that the whorl height mainly responded by increasing in the presence of the worm tube. Consequently, the coiling rate of the conch also increased. As an increase in the coiling rate causes shortening of the body chamber (measured in angle degrees), this might have been facilitated by the specimen to maintain neutral buoyancy.

The morphological changes of the conch geometry, which occur in the specimen as a result of worm infestation from the tenth half-volution, need to be considered in more detail. The focus of the investigation is on the deviation of the affected whorls from the vertical symmetry axis (and thus from planispiral coiling) of the specimen. As usual for ammonoids, the growth of the conch was bilaterally symmetrical but with a variety of deviations from isometric growth (Korn, 2012) and in the absence of disturbing factors such as a worm tube on the external side of the conch or severe injuries of the shell (e.g. Keupp, 2012; Hoffmann and Keupp, 2015). Individuals with undisturbed growth may orient themselves, in the course of coiling, on the keel of the preceding volution. This is described as the road-holding model in gastropods (Hutchinson, 1989) and hypothesized as the piggyback whorl model in ammonoids (Ubukata et al., 2008). The existence of the worm tube misled the ammonoid examined here to align the subsequent whorls with the worm tube. The displacement caused by the worm tube therefore results in a lateral displacement of the whorls oriented thereon. The first half-whorl affected by the worm tube shows a strong deviation (about 5 degrees) relative to the axis of symmetry of the ammonite (Fig. 5a). Along the following volutions, the specimen appears to compensate for this deviation: the angles of deviation of the individual half-whorls oscillate around the axis of symmetry; the amplitude (i.e., the amount of deviation) decreases in the course of ontogeny.

\section{Discussion and conclusion}

It is evident that the worm tube was entirely overgrown by the ammonite in the course of building ontogenetically later volutions. These volutions orient themselves during their growth on the serpulid tube and show conspicuous deviations from the normal conch symmetry.

The ammonite specimen was facing three major problems when infested by the serpulid:

1. Disruption of the vertical alignment of the conch in life position. The worm tube was not attached on the midventer but had a position on the left side of the venter. The extra weight of the tube thus had an effect on the orientation of the vertical axis.

2. Change of orientation of the aperture in life position. The extra weight possibly caused a more downward orientation of the aperture because of a relative shift in the centres of mass and buoyancy (e.g. Saunders and
Shapiro, 1986; Naglik et al., 2015; Tajika et al., 2015; Naglik et al., 2016). This probably occurred because the worm tube aperture stayed close to the aperture of the ammonite conch, thereby accumulating additional mass at the greatest possible distance from the centre of mass. Additionally, the altered conch geometry likely caused a shortening in body chamber length and also shifted the aperture slightly downward. Since the ammonite survived the worm infestation without big problems, the effect of the epizoan was probably not very severe for the ammonite host.

3. Negative buoyancy. To maintain neutral buoyancy, the specimen had to compensate the extra weight of the worm tube. This could have been done by a modification of the shell-phragmocone space ratio, a reduction of body chamber length or the reduction of cameral liquid.

Morphometric investigations of the conch geometry of specimen MB.C. 27997 of Pararnioceras sp. demonstrates the ability of the ammonite to counteract a pathological conch abnormality due to worm infestation by actively changing the orientation of subsequent whorls. In this case, the animal used the serpulid tube instead of the keel of the preceding whorl for orientation according to the road holding model. The anomaly can be classified as forma aegra undatispirata (Keupp and Ilg, 1992) and is characterized by a pendulum of the affected whorls (Keupp, 2012), which is seen in the specimen in the form of a whorl deviation oscillating about the axis of symmetry of the ammonite.

According to Checa et al. (2002), the anomaly compensating growth of the specimen serves not only to maintain the equilibrium position in the water column, but also to ensure the correct aperture orientation, which is a prerequisite for the ammonite's buoyancy pursuing a nektonic lifestyle (Klug et al., 2004, 2010; Stilkerich et al., 2017).

The cross-sectional drawing of the specimen shows that the worm tube was attached to the ammonite conch over three half-volutions. The fact that the volutions impaired by the worm tube in the course of ontogeny are connected with further whorls shows that the animal has survived the worm infestation. Furthermore, the specimen has maintained a way of life which enabled it to continue conch growth by at least two further whorls. The survival of the host was also important for the worm itself, since it could only take advantage of the interrelationship over a longer period (Meischner, 1968; Andrew et al., 2011; Hautmann et al., 2017).

Based on our study, the extent to which the specimen was able to maintain the hydrodynamic equilibrium in the water column, especially in the ontogenetic stages immediately following worm infestation, must remain investigated. The question of the floatability of the specimen under the influence of the epizoan parasite cannot be answered in the course of this study. 
It is remarkable how tolerant ammonites were towards epizoans. Epizoans are commonly encountered in numerous ammonite species (e.g. Seilacher, 1960; Keupp et al., 1999; Klug and Korn, 2001; Klug et al., 2004; Tajika et al., 2015), while in nautilids, such cases are much rarer (e.g. Landman et al., 2010). However, epizoans evidently altered the buoyancy of the ammonoid conch and caused the cephalopod's reaction to compensate for the added mass and to ultimately maintain neutral buoyancy (Klug et al., 2004). These reactions represent an indirect proof for the importance of neutral buoyancy of ammonoids and for their habitat within the water column, be it close to the sediment surface (nektobenthic) or higher (nektonic to planktonic, depending on conch shape (Naglik et al., 2015).

Data availability. The data utilized in this article can be found in the Supplement.

Supplement. The supplement related to this article is available online at: https://doi.org/10.5194/fr-21-67-2018-supplement.

Competing interests. The authors declare that they have no conflict of interest.

Acknowledgements. We acknowledge Kevin Page (Plymouth) for the discussion of the arietitid taxa studied here. Many thanks to Kenneth De Baets (Erlangen) and Helmut Keupp (Berlin) for reviewing an earlier version of the manuscript. Carina Klein acknowledges the Elsa Neumann Foundation for their financial support.

Edited by: Rene Hoffmann

Reviewed by: Helmut Keupp and Kenneth De Baets

\section{References}

Andrew, C., Howe, P., Paul, C. R., and Donovan, S. K.: Epifaunal worm tubes on Lower Jurassic (Lower Lias) ammonites from Dorset, P. Geologist. Assoc., 122, 34-46, 2011.

Bockwinkel, J., Becker, R. T., and Ebbighausen, V.: Upper Givetian ammonoids from Dar Kaoua (Tafilalt, SE Anti-Atlas, Morocco), Berliner paläobiologische Abhandlungen, 10, 61-128, 2009.

Bucher, H., Landman, N. H., Klofak, S. M., and Guex, J.: Mode and Rate of Growth in Ammonoids, in: Ammonoid Paleobiology - Topics of Geobiology 13, edited by: Landman, N. H., Tanabe, K., and Davis, R. A., Plenum Press, New York, USA and London, UK, 407-461, 1996.

Buys, J.: Symbiosen van serpula's met ammonitien uit de Onder Lias van Dorset (Zuid-Engeland), Grundboor en Hamer, 1973, 62-67, 1973.
Checa, A. G., Okamoto, T., and Keupp, H.: Abnormalities as natural experiments: a morphogenetic model for coiling regulation in planispiral ammonites, Paleobiology, 28, 127-138, 2002.

Davis, R. A., Mapes, R. H., and Klofak, S. M.: Epizoa on externally shelled cephalopods, in: Fossil cephalopods: Recent advances in their study, edited by: Rozanov, A. Y. and Shevyrev, A. A., Paleontologicheskogo Instituta Rossiyskaya Akademiya Nauk, Moscow, Russia, 32-51, 1999.

De Baets, K., Klug, C., and Korn, D.: Devonian pearls and ammonoid-endoparasite co-evolution, Acta Palaeontol. Pol., 56, 159-180, https://doi.org/10.4202/app.2010.0044, 2011.

De Baets, K., Klug, C., Korn, D., Bartels, C., and Poschmann, M.: Emsian Ammonoidea and the age of the Hunsrück Slate (Rhenish Mountains, Western Germany), Palaeontogr. Abt. A, 299, 1113, 2013.

De Baets, K., Keupp, H., and Klug, C.: Parasites of ammonoids, in: Ammonoid Paleobiology: From anatomy to ecology, edited by: Klug, C., Korn, D., De Baets, K., Kruta, I., and Mapes, R. H., Topics in Geobiology, 43, Springer, Dordrecht, the Netherlands, 2015.

Donovan, D., Callomon, J. H., and Howarth, M. K.: Classification of the Jurassic ammonitina, in: The Ammonoidea, Academic Press London, London, UK, 101-155, 1981.

d'Orbigny, A. D.: Paléontologie française; description zoologique et géologique de tous les animaux mollusques et rayonnés fossiles de France, comprenant leur application a la reconnaissance des couches, Ser. 1, Jurassiques, tome 1., M. J. Delarue, Paris, 1842.

Ehrenberg, Ê.: Besprechung von W. Lange: Über Symbiosen von Serpula mit Ammoniten im unteren Lias Norddeutschlands, Palaeontologisches Zentralblatt, 2, p. 87, 1932.

Fraaye, R. and Jäger, M.: Decapods in ammonite shells: examples of inquilinism from the Jurassic of England and Germany, Palaeontology, 38, 63-76, 1995.

Hautmann, M., Ware, D., and Bucher, H.: Geologically oldest oysters were epizoans on Early Triassic ammonoids, J. Mollus. Stud., 83, 253-260, 2017.

Haven, N.: The ecology and behavior of Nautilus pompilius in the Philippines, Veliger, 15, 75-80, 1972.

Hengsbach, R.: Die Symmetropathie, ein Beitrag zur Erforschung so genannter Anomalien, Senckenbergiana lethaea, 71, 339-366, 1991.

Hengsbach, R.: Ammonoid pathology, in: Ammonoid paleobiology, edited by: Landman, N. H., Tanabe, K., and Mapes, R. H., Topics in Geobiology, 13, Plenum Press, New York, USA, 1996.

Ho, J.-S.: Anchicallgus nautili (Willey), a caligid copepod parasitic on Nautilus in Palau, with discussion of Caligulina Heegard, 1972, P. Seto Mar, Biol. Lab., 25, 157-165, 1980.

Hoffmann, R. and Keupp, H.: Ammonoid paleopathology, in: Ammonoid Paleobiology: From anatomy to ecology, edited by: Klug, C., Korn, D., De Baets, K., Kruta, I., and Mapes, R. H., Topics in Geobiology, 43, Springer, Dordrecht, the Netherlands, 2015.

Hölder, H.: Über Anomalien an jurassischen Ammoniten, Palaeont. Z., 30, 95-107, 1956.

Holland, C. H.: Some conspicuous participants in Palaeozoic symbiosis, Scientific Proceedings of the Royal Dublin Society A, 4, 15-26, 1971.

Hutchinson, J.: Control of gastropod shell shape; the role of the preceding whorl, J. Theor. Biol., 140, 431-444, 1989. 
Hyatt, A.: Genesis of the Arietidae, Smithsonian Contributions to Knowledge, 26, 1-673, 1889.

Jäger, M.: Nicht alltäglich: Ein Ammonit mit zwei Spiralen, Fossilien, 1991, 351-353, 1991.

Keupp, H.: Atlas zur Paläopathologie der Cephalopoden, Berliner Paläobiologische Abhandlungen, 12, 1-390, 2012.

Keupp, H. and Ilg, A.: Paläopathologie der Ammonitenfauna aus dem Obercallovium der Normandie und ihre palökologische Interpretation, Berliner Geowissenschaftlische Abhhandlungen E, 3, 171-189, 1992.

Keupp, H., Röper, M., and Seilacher, A.: Paläobiologische Aspekte von syn vivo-besiedelten Ammonoideen im Plattenkalk des Ober-Kimmeridgiums von Brunn in Ostbayern, Berliner Geowissenschaftliche Abhandlungen E, 30, 121-145, 1999.

Keupp, H., Röper, M., and Rothgaenger, M.: Serpuliden-Epökie auf Ammoniten aus dem Brunner Plattenkalk (Ober-Kimmeridgium) in Ostbayern, Archaeopteryx, 29, 1-12, 2011.

Klug, C.: Life-cycles of some Devonian ammonoids, Lethaia, 34, 215-233, 2001.

Klug, C. and Korn, D.: Epizoa and post-mortem epicoles on cephalopod shells-Devonian and Carboniferous examples from Morocco, Berliner geowissenschaftliche Abhandlungen E, 36, 145-155, 2001.

Klug, C., Korn, D., and Richter, U.: The black layer in cephalopods from the German Muschelkalk (Triassic), Palaeontology, 47, 1407-1425, 2004.

Klug, C., Kröger, B., Kiessling, W., Mullins, G. L., Servais, T., Fryda, J., Korn, D., and Turner, S.: The Devonian nekton revolution, Lethaia, 43, 465-477, 2010.

Klug, C., Korn, D., Landman, N. H., Tanabe, K., De Baets, K., and Naglik, C.: Describing ammonoid conchs, in: Ammonoid Paleobiology: From anatomy to ecology, edited by: Klug, C., Korn, D., De Baets, K., Kruta, I., and Mapes, R. H., Topics in Geobiology, 43, Springer, Dordrecht, the Netherlands, 2015.

Korn, D.: Die Ammonoideen-Fauna der Platyclymenia annulataZone vom Kattensiepen (Oberdevon, Rheinisches Schiefergebirge), Senckenbergiana lethaea, 82, 557-608, 2002.

Korn, D.: A key for the description of Palaeozoic ammonoids, Fossil Record, 13, 5-12, 2010.

Korn, D.: Quantification of ontogenetic allometry in ammonoids, Evolution \& Development, 14, 501-514, 2012.

Korn, D. and Price, J. D.: Taxonomy and Phylogeny of the Kosmoclymeniinae subfam.nov. (Cephalopoda, Ammonoidea, Clymeniida), Cour. Forsch. Senck., 92, 5-75, 1987.

Kraft, S., Korn, D., and Klug, C.: Patterns of ontogenetic septal spacing in Carboniferous ammonoids, Neues Jahrb. Geol. P.-A., 250, 31-44, 2008.

Landman, N. H. and Waage, K. M.: Shell abnormalities in scaphitid ammonites, Lethaia, 19, 211-224, 1986.

Landman, N. H., Saunders, W. B., Winston, J. E., and Harries, P. J.: Incidence and kinds of epizoans on the shells of live Nautilus, Nautilus - the biology and paleobiology of a living fossil, edited by: Saunders, W. B. and Landman, N. H., Plenum Press, New York, USA, 2010.

Lange, W.: Über Symbiosen von Serpula mit Ammoniten im unteren Lias Norddeutschlands, Z. Dtsch. Ges. Geowiss., 1932, 229-234, 1932.

Linck, O.: Echte und unechte Besiedler (Epöken) des deutschen Muschelkalk-Meeres, Aus der Heimat, 64, 161-173, 1956.
Luci, L. and Cichowolski, M.: Encrustation in nautilids: a case study in the Cretaceous species Cymatoceras perstriatum, Neuquén Basin, Argentina, Palaios, 29, 101-120, 2014.

Meischner, D.: Perniciöse Epökie von Placunopsis auf Ceratites, Lethaia, 1, 156-174, 1968.

Merkt, J.: Über Austern und Serpeln als Epöken auf Ammonitengehäusen, Neues Jahrb. Geol. P.-A., 125, 467-479, 1966.

Naglik, C., Tajika, A., Chamberlain, J., and Klug, C.: Ammonoid locomotion, in: Ammonoid Paleobiology: From anatomy to ecology, edited by: Klug, C., Korn, D., De Baets, K., Kruta, I., and Mapes, R. H., Topics in Geobiology, 43, Springer, Dordrecht, the Netherlands, 2015.

Naglik, C., Rikhtegar, F., and Klug, C.: Buoyancy of some Palaeozoic ammonoids and their hydrostatic properties based on empirical 3D-models, Lethaia, 49, 3-12, 2016.

Neige, P., Dera, G., and Dommergues, J. L.: Adaptive radiation in the fossil record: a case study among Jurassic ammonoids, Palaeontology, 56, 1247-1261, 2013.

Nicosia, U.: Ammonites/epizoans relationships in the Kimmeridgian of the Central Apennines, Geologica Romana, 25, 155-164, 1986.

Nikolaeva, S. V. and Bogoslovsky, B. I.: Late Famennian ammonoids, from the upper part of the Kiya Formation of the South Urals, Paleontological J., 39, 527-537, 2005.

Quenstedt, F. A.: Der Jura, Schweizerbart, Tübingen, Germany, 1858.

Quenstedt, F. A.: Die Ammoniten des Schwäbischen Jura, Schweizerbart, Stuttgart, Germany, 1885-1888.

Rakús, M. and Zítt, J.: Crinoid encrusters of ammonite shells (Carixian, Tunisia), Geobios, 26, 317-329, 1993.

Saunders, W. B. and Shapiro, E. A.: Calculation and simulation of ammonoid hydrostatics, Paleobiology, 64-79, 1986.

Schindewolf, O. H.: Über Epöken auf Cephalopoden-Gehäusen, Palaeontol. Z., 16, 15-31, 1934.

Schmid-Röhl, A. and Röhl, H. J.: Overgrowth on ammonite conchs: environmental implications for the Lower Toarcian Posidonia Shale, Palaeontology, 46, 339-352, 2003.

Seilacher, A.: Epizoans as a key to ammonoid ecology, J. Paleontol., 34, 189-193, 1960.

Seilacher, A.: Ammonite shells as habitats in the Posidonia Shales of Holzmaden - floats or benthic islands?, Neues Jahrb. Geol. P.-M., 1982, 98-114, 1982.

Sowerby, J.: The Mineral Conchology of Great Britain: Or coloured figures and descriptions of those remains of testaceous animals or shells, which have been preserved at various times and depths in the Earth, Vol. V., Meredith, London, UK, 1825.

Spinosa, C., Furnish, W. M., and Glenister, B. F.: The Xenodiscidae, Permian ceratoid ammonoids., J. Paleontol., 49, 239-283, 1975.

Stevens, G.: Giant ammonites: a review, Cephalopods: present and past, Schweizerbart, Stuttgart, Germany, 141-166, 1988.

Stilkerich, J., Smrecak, T. A., and De Baets, K.: 3DAnalysis of a non-planispiral ammonoid from the Hunsrück Slate: natural or pathological variation?, PeerJ, 5, e3526, https://doi.org/10.7717/peerj.3526, 2017.

Tajika, A., Naglik, C., Morimoto, N., Pascual-Cebrian, E., Hennhöfer, D., and Klug, C.: Empirical 3D model of the conch of the Middle Jurassic ammonite microconch Normannites: its buoyancy, the physical effects of its mature modifications and speculations on their function, Hist. Biol., 27, 181-191, 2015. 
Turek, V.: On some epizoans of molluscs shells from the Upper Silurian (Pridolian) of the Barrandian area, Věstník Ústředního ústavu geologického, 62, 105-111, 1987.

Ubukata, T., Tanabe, K., Shigeta, Y., Maeda, H., and Mapes, R. H.: Piggyback whorls: A new theoretical morphologic model reveals constructional linkages among morphological characters in ammonoids, Acta Palaeontol. Pol., 53, 113-128, 2008.

Wähner, R. A.: Beitrag zur Kenntnis der tieferen Zonen des unteren Lias in den nordostlichen Alpen, Beiträge zur Paläontologie Österreich-Ungarns und des Orients, 9, 1-54, 1895.
Walton, S. A. and Korn, D.: Iterative ontogenetic development of ammonoid conch shapes from the Devonian through to the Jurassic, Palaeontology, 60, 703-726, 2017.

Westermann, G. E. G.: Form, structure and function of shell and siphuncle in coiled Mesozoic ammonoids, Life Science Contributions of the Royal Ontario Museum, 78, 1-3, 1971.

Zapalski, M. K.: Is absence of proof a proof of absence? Comments on commensalism, Palaeogeogr. Palaeocl., 302, 484-488, 2011. 